\title{
Documentation of ritual plants used among the Aceh tribe in Peureulak, East Aceh District, Indonesia
}

\author{
IMAM HADI SUTRISNO ${ }^{1, \bullet}$, BACHTIAR AKOB ${ }^{1}$, ZIDNI ILMAN NAVIA $^{2}$, NURAINI ${ }^{3}$, ADI BEJO SUWARDI ${ }^{3}$ \\ ${ }^{1}$ Department of History Education, Faculty of Teacher Training and Education, Universias Samudra. Jl. Meurandeh, Langsa 24354, Aceh, Indonesia, \\ Tel.: +62-641-426535, `email: hadi_sutrisno@unsam.ac.id \\ ${ }^{2}$ Department of Biology, Faculty of Engineering, Universitas Samudra. Jl. Meurandeh, Langsa 24354, Aceh, Indonesia \\ ${ }^{3}$ Department of Biology Education, Faculty of Teacher Training and Education, Universitas Samudra. Jl. Meurandeh, Langsa 24354, Aceh, Indonesia
}

Manuscript received: 13 September 2020. Revision accepted: 3 October 2020

\begin{abstract}
Sutrisno IH, Akob B, Navia ZI, Nuraini, Suwardi AB. 2020. Documentation of ritual plants used among the Aceh tribe in Peureulak sub-district, East Aceh, Indonesia. Biodiversitas 21: 4990-4998. Traditional ceremonies as part of human cultural products at a practical level cannot be separated from the use of natural resources, mainly plants. Concerning the use of plants in traditional ceremonies, the knowledge and use of plants by the community are decreasing. This study aims to document the ritual plants used by the Aceh tribe in the East Aceh district of Indonesia. The study was conducted in Peureulak sub-districts, East Aceh district, Indonesia. A field survey was involved 125 respondents were selected using random sampling. The interview used a questionnaire including plant species, vernacular names, uses, parts use, and ritual tradition. A total of 51 ritual plant species consisting of 47 genera and 34 families was used as ritual ceremonies in the study area. Ninety-two percent were cultivated and $8 \%$ were found to be growing wild. Most of the plants used for wedding ceremonies (18 species), followed by birth ceremonies ( 8 species), funeral ceremonies (5 species), and pregnancy ceremony ( 3 species). Socio-cultural aspects can be considered as being used for the conservation of ritual plants in the East Aceh region.
\end{abstract}

Keywords: Ceremonial, East Aceh, Peureulak, peusijeuk, traditional knowledge

\section{INTRODUCTION}

The relationship between human beings and their environment is quite adjacent and has been going on for a long time (Hakim 2014). Human population growth associated with land-use change has had a serious impact on nature. Alteration of habitats and related biological changes has affected the existence of important plant species. Plants play a very important role in a larger number of human populations, particularly in rural communities. In the rural area, plants are the important source of food, medicine, condiment, and construction material to build houses (Navia et al. 2015; Suwardi et al. 2018; Navia et al. 2019a; Elfrida et al. 2020; Navia et al. 2020a; Navia et al. 2020b; Suwardi et al. 2020a). In addition, several plants are part of various ritual purposes (Sharma and Pegu 2011; Iskandar and Iskandar 2017), as well as a source of livelihood for the local people (Rajbhandary and Ranjitkar 2006; Navia et al. 2019b; Suwardi et al. 2020b). Plants have many cultural aspects, e.g. language, history, art, religion, politics, and social structure (Kakudidi 2004). Knowledge of the cultural significance of plants and forests can be gathered from ethnobotanical and ethnomedical studies (Suwardi et al. 2019; Navia et al. 2020a; Suwardi et al. 2020c). Conservation of natural resources is very important and effective when expertise is combined with understanding and awareness of the cultural practices of local communities (Sheybani et al. 2015; O'Neill et al. 2017). Ritual beliefs of indigenous peoples are one of the most important tools for understanding local communities and offering to help to conserve nature (Geng et al. 2017). Many communities maintain their tradition across folklore and adopt ritual beliefs (Sharma and Pegu 2011), which can provide useful information and links to biodiversity conservation. Conserving biodiversity based on culture and religion is more reliable and efficient than legislation or regulation (Liu et al. 2002).

Plants in local Indonesian ethnicity have an important meaning, especially those used in different religious ceremonies (Hulyati et al. 2014; Helida et al. 2015; Anggraini et al. 2018; Ristanto et al. 2020), including in the Aceh tribe. The number of plants used in ceremonials is different and varied and often has symbols that may vary from one species to another (Putri et al. 2014). The role of one species cannot be replaced by other species in ritual ceremonies. Besides the primary purpose related to symbols, this feature is as a path of guidance, peace of mind, comfort in ritual life, so use these plant species believed can trigger disasters for local people (Koentjaraningkrat 2009). Numerous plants have been used in traditional ceremonies, such as Oryza sativa L., Manihot esculenta Crantz., Areca catechu L., Allium sativum L., Kaempferia galanga L., Carica papaya L., Cocos nucifera L., Curcuma longa L., and Arenga pinnata Merr. (Mutaqin et al. 2018). These species have a main function related to symbolism (Supinah 2006; Iskandar and Iskandar 2017).

Technology and information developments are reported to have led to a decline in traditional knowledge of local communities in different regions (Putri et al. 2017; Navia et 
al. 2020b; Suwardi et al. 2020c). The condition may also have an impact on the Acehnese tradition in Peureulak, - in particular the use of various plants in ritual ceremonies, given that modernization has influenced the lifestyle of the young generation. In addition, documentation on the use of plants used in traditional ceremonies is limited, and knowledge transfer from generation to generation is mostly conducted orally (Surata et al. 2015). However, traditional knowledge of environmental management is crucial for the conservation of biodiversity (Iskandar and Iskandar 2017). This study aims to document the ritual plants used by the Aceh tribe in the East Aceh district of Indonesia.

\section{MATERIALS AND METHODS}

\section{Study area}

The study was conducted in Peureulak sub-districts

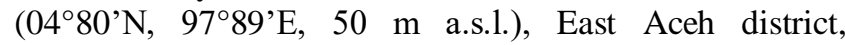
Indonesia as shown in Figure 1. Peureulak sub-district has an area of $318.02 \mathrm{~km}^{2}$ with a total population of 74,697 people, comprising $50.1 \%$ men and $49.9 \%$ women. These areas have a tropical humid climate with a dry season predominantly occurring from January to July while the rainy season lasts from August to December. The average temperature is around $26^{\circ} \mathrm{C}-30^{\circ} \mathrm{C}$. The topography is generally sloping and the zone is characterized by a cropping system where rice and vegetables make up the primary crops (The Central Bureau of Statistics of East Aceh District 2020).

\section{Data collection}

The study was conducted in Peureulak sub-districts, East Aceh district, Indonesia. A field survey was involved 125 respondents were selected using random sampling (Table 1). The interview was conducted face to face and each interview lasted between 30 and 60 minutes. The interview used a questionnaire including plant species, vernacular names, uses, parts use, and ritual tradition.

Plant identification is performed directly on the field. If a species of the unknown scientific name has been recognized in the survey, plant specimens have been collected, local names are recorded and identified in the Biology Laboratory of the Samudra University. Plant identification refers to identification books such as the Flora of Java (Backer and Bakhuizen van den Brink 1980), Key to the families of flowering plants of the world (Hutchinson 1967), and the Indonesian useful plants (Heyne 1987). The botanical names have been updated using The Plant List (www.theplantlist.org), Plants of the World (www.plantsoftheworldonline.org), and the International Plant Name Index (www.ipni.org).

\section{Data analysis}

The data were analyzed by determining the Cultural Significance Index (CSI) value using the technique developed by Turner (1988) with the following formula:

$$
C S I=\sum_{i=1}^{n}\left(q_{1} x i_{1} x e_{1}\right) n_{1}
$$

Where: CSI = Cultural Significance Index; $q$ = quality value; $\mathrm{i}=$ intensity value; $\mathrm{e}=$ exclusivity value.

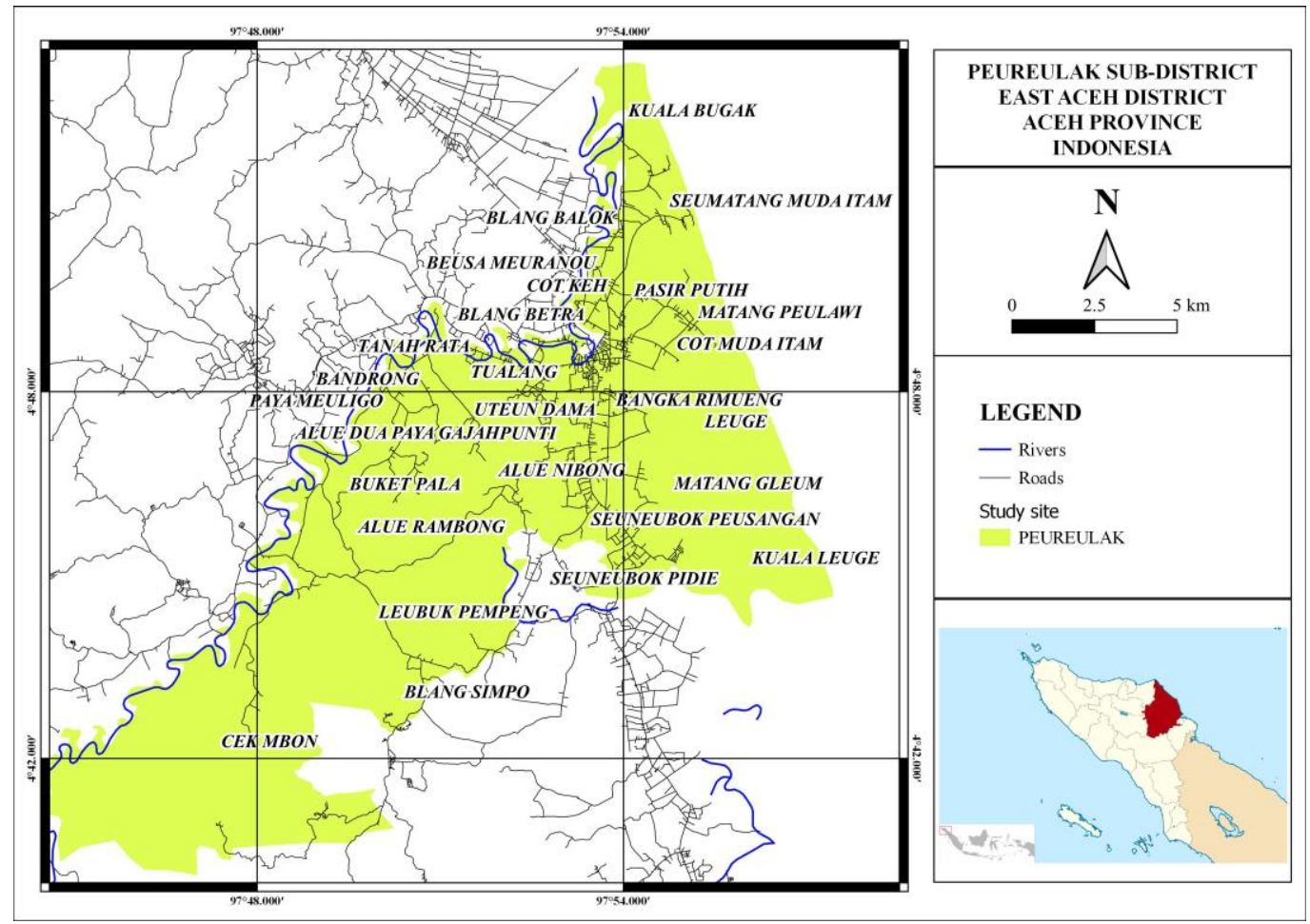

Figure 1. Map of East Aceh District, Aceh Province, Indonesia, showing the study area 
Table 1. The demographic structure of respondents

\begin{tabular}{llcc}
\hline Parameter & Specification & Freq. & Percent. \\
\hline Gender & Male & 52 & 41.6 \\
& Female & 73 & 58.4 \\
& $15-25$ & 21 & 16.8 \\
& $26-35$ & 28 & 22.4 \\
& $36-45$ & 26 & 20.8 \\
& $46-55$ & 29 & 23.2 \\
& $56-65$ & 17 & 13.6 \\
& $>65$ & 4 & 3.2 \\
& None & 24 & 19.2 \\
& Elementary School & 39 & 31.2 \\
& Yunior High School & 32 & 25.6 \\
& Senior High School & 18 & 14.4 \\
& University & 12 & 9.6 \\
\hline
\end{tabular}

\section{RESULTS AND DISCUSSION}

\section{Floristic composition of ritual plants}

The survey results revealed the Aceh tribe possessed of the traditional ritual plants. A total of 51 species consisting of 47 genera and 34 families was used as ritual ceremonies in the study area (Table 2).

Poaceae was the largest family of six species, followed by Arecaceae (4 species), Rosaceae, Rutaceae, and Sapindaceae (3 species each), Amaranthaceae, Myrtaceae, and Zingiberaceae (2 species each), while other families contributed as many as 1 species. Ninety-two percent were cultivated and $8 \%$ were found to be growing wild. Twenty $(39 \%)$ species were found growing in the home garden, 15 $(29 \%)$ species in farmland, and $13(26 \%)$ species occurred in both the home garden and farmland, and $3(6 \%)$ species purchased from the traditional market. The number of species recorded in this study (51 species) was comparable to the 50 ritual plant species reported in Bandung, Indonesia (Iskandar and Iskandar 2017), but lower than that in Bali, Indonesia, i.e., 125 species (Sujarwo et al. 2019)

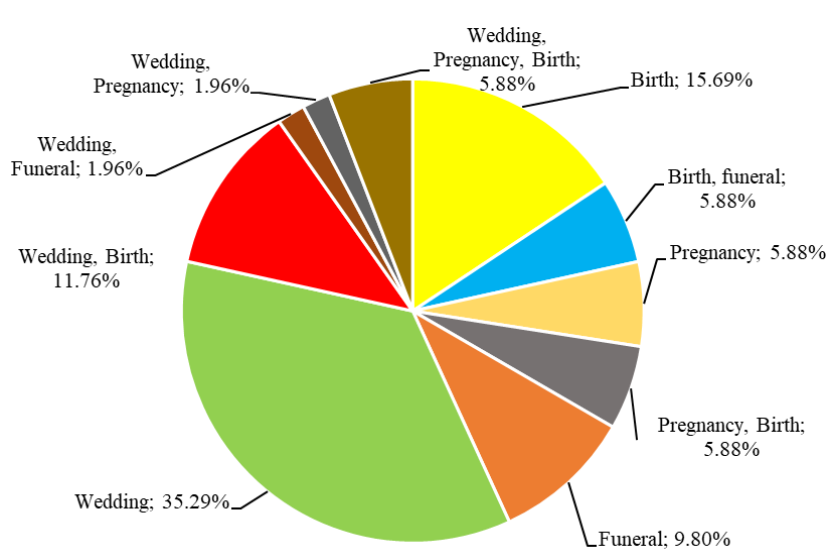

Figure 2. Percentage of plant material for ritual ceremonies and 60 species in East Nusa Tenggara, Indonesia (Sada and Jumari 2018). However, it was higher than the 36 ritual plant species reported in the Banswara district, India (Rana et al. 2016), in Jambi, Indonesia, i.e., 32 species (Hariyadi and Ticktin 2012), in Yunnan Province, Southwest China, i.e., 32 species (Geng et al. 2017), in Nigeria, i.e. 31 species (Kadiri et al. 2014), and 21 ritual plant species reported in the Pangandaran, Indonesia (Mutaqin et al. 2018). Most of the plants used for wedding ceremonies $(36 \%)$, followed by birth ceremonies (16\%), funeral ceremonies $(10 \%)$, pregnancy ceremony $(6 \%)$, and remain plant species have multipurpose (Figure 2). The results showed that the use of fruits was more dominant than other parts of the plant (Figure 3).

According to data analysis, the Cultural Significance Index (CSI) of 51 ritual plant species ranged from 6-60. The highest CSI value was for Oryza sativa and Musa paradisiaca (60). This species is used at almost all stages of the ceremony, as well as being the main component that is very important and cannot be replaced by other species. While Artocarpus heterophyllus, Averrhoa carambola, Carica papaya, Citrullus lanatus, Citrus maxima, Dimocarpus longan, Durio zibethinus, Malus domestica, Manilkara zapota, Nephelium lappaceum, Phoenix dactylifera, Pogostemon cablin, Pyrus communis, Syzygium aqueum, and Vitis vinifera have the lowest CSI value (6). This indicates that these species may be replaced by other species as a component of the ritual ceremony. Species with low CSI values reveal that these species meet only secondary needs with low preference levels (Mirawati 2014).

\section{Plants in ceremonial of the Aceh tribe}

The Aceh tribe has unique traditions, such as wedding, pregnancy, birth, funeral, and others, which are always preserved, and several local plants available are an important part of these rituals. The various plant species used by the Aceh tribe during traditional ceremonies are shown in Table 3.

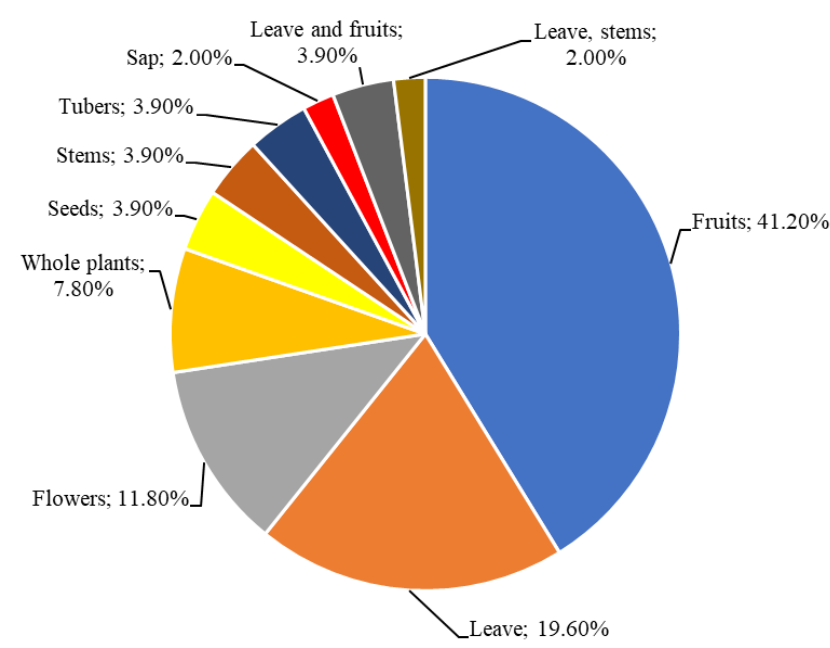

Figure 3. Percentage of plant part used for ritual ceremonies 
Table 2. Ritual plants used by the Aceh tribe, East Aceh, Indonesia

\begin{tabular}{|c|c|c|c|c|c|c|c|c|}
\hline Scientific name & Family & Local name & Life form & Location & Status & Part used & Ceremonies & CSI \\
\hline Acorus calamus $\mathrm{L}$. & Acoraceae & Jerengo & Herb & $\mathrm{HG}$ & Wild & Leave & Birth & 20 \\
\hline Aerva lanata (L.) Juss. ex Schult & Amaranthaceae & Manek manoe & Herb & HG & Cultivated & Flowers & Wedding, birth & 40 \\
\hline Amaranthus hybridus L. & Amaranthaceae & Bayam & Herb & $\mathrm{HG}, \mathrm{FL}$ & Cultivated & Whole plants & Birth & 10 \\
\hline Ananas comosus (L.) Merr & Bromeliaceae & Nanas & Herb & $\mathrm{HG}, \mathrm{FL}$ & Cultivated & Fruits & Wedding & 8 \\
\hline Areca catechu $\mathrm{L}$. & Arecaceae & Pineung & Palm & $\mathrm{HG}, \mathrm{FL}$ & Cultivated & Leave, seeds & Wedding, birth & 40 \\
\hline Artocarpus heterophyllus Lam. & Moraceae & Nangka & Tree & $\mathrm{HG}$ & Cultivated & Fruits & Birth & 6 \\
\hline Averrhoa carambola $\mathrm{L}$. & Oxalidaceae & Belimbing & Tree & $\mathrm{HG}$ & Cultivated & Leave & Funeral & 6 \\
\hline Bambusa sp. & Poaceae & Bambu & Shrub & $\mathrm{HG}, \mathrm{FL}$ & Wild & Stems & Birth & 8 \\
\hline Bougainvillea spectabilis Willd. & Nyctaginaceae & Bunga kertas & Shrub & $\mathrm{HG}$ & Cultivated & Flowers & Wedding, funeral & 32 \\
\hline Bryophyllum pinnatum (Lam.) Oken & Crassulaceae & Cocor bebek & Herb & HG & Cultivated & Leaves & Wedding, birth & 32 \\
\hline Cananga odorata (Lam.) Hook.f. \& Thomson & Annonaceae & Kenanga & Tree & HG & Cultivated & Flowers & Birth, funeral & 40 \\
\hline Carica papaya $\mathrm{L}$ & Caricaceae & Pepaya & Tree & $\mathrm{HG}, \mathrm{FL}$ & Cultivated & Fruits & Wedding & 6 \\
\hline Citrullus lanatus (Thunb.) Matsum. \& Nakai & Cucurbitaceae & Semangka & Vein & FL & Cultivated & Fruits & Wedding & 6 \\
\hline Citrus hystrix DC. & Rutaceae & Jeruk purut & Tree & FL & Cultivated & Fruits & Wedding & 20 \\
\hline Citrus maxima (Burm.) Merr. & Rutaceae & Jeruk bali & Tree & FL & Cultivated & Fruits & Pregnancy & 6 \\
\hline Citrus aurantium $\mathrm{L}$. & Rutaceae & Jeruk & Tree & FL & Cultivated & Fruits & Birth & 8 \\
\hline Cocos nucifera $\mathrm{L}$. & Arecaceae & Kelapa & Palm & HG, FL & Cultivated & Leave and fruits & Pregnancy, birth & 40 \\
\hline Codiaeum variegatum (L.) Rumph. ex A.Juss. & Euphorbiaceae & Puring & Shrub & $\mathrm{HG}$ & Cultivated & Leave, stems & Wedding & 8 \\
\hline Colocasia esculenta (L.) Schot & Araceae & Keladi & Herb & HG, FL & Cultivated & Leave & Birth & 8 \\
\hline Curcuma longa $\mathrm{L}$. & Zingiberaceae & Kunyit & Herb & $\mathrm{HG}$ & Cultivated & Tubers & Wedding & 20 \\
\hline Cynodon dactylon (L.) Pers. & Poaceae & Naleung samboe & Graminoid & HG & Wild & Whole plants & Wedding, birth & 40 \\
\hline Cyrtostachys renda Blume & Arecaceae & Pinang merah & Palm & HG & Cultivated & Seeds & Wedding & 10 \\
\hline Dimocarpus longan Lour. & Sapindaceae & Kelengkeng & Tree & HG & Cultivated & Fruits & Wedding & 6 \\
\hline Durio zibethinus L. & Malvaceae & Durian & Tree & FL & Cultivated & Fruits & Pregnancy & 6 \\
\hline Eleusine indica (L.) Gaertn. & Poaceae & Rumput belulang & Graminoid & HG & Wild & Whole plants & Wedding, birth & 40 \\
\hline Jasminum sambac (L.) Aiton & Oleaceae & Melati & Shrub & HG & Cultivated & Flowers & Birth, funeral & 40 \\
\hline Kaempferia galanga $\mathrm{L}$. & Zingiberaceae & Cekur & Herb & HG & Cultivated & Tubers & Wedding & 20 \\
\hline $\begin{array}{l}\text { Lansium parasiticum (Osbeck) K.C.Sahni \& } \\
\text { Bennet }\end{array}$ & Sapindaceae & Duku & Tree & FL & Cultivated & Fruits & Wedding, pregnancy & 12 \\
\hline Lawsonia inermis L. & Lythraceae & Inai & Herb & HG & Cultivated & Leaves & Wedding, birth & 40 \\
\hline Magnolia champaca (L.) Baill. ex Pierre & Magnoliaceae & Cempaka & Tree & HG & Cultivated & Flowers & Funeral & 20 \\
\hline Malus domestica Borkh. & Rosaceae & Apel & Tree & MR & Cultivated & Fruits & Wedding & 6 \\
\hline Mangifera indica $\mathrm{L}$. & Anacardiaceae & Mangga & Tree & HG, FL & Cultivated & Fruits & Wedding, pregnancy, birth & 12 \\
\hline Manilkara zapota (L.) P.Royen & Sapotaceae & Sawo & Tree & $\mathrm{HG}, \mathrm{FL}$ & Cultivated & Fruits & Pregnancy & 6 \\
\hline Musa paradisiaca $\mathrm{L}$. & Musaceae & Pisang & Herb & FL & Cultivated & Leaves and fruits & Wedding, pregnancy, birth & 60 \\
\hline Nephelium lappaceum L. & Sapindaceae & Rambutan & Tree & $\mathrm{HG}, \mathrm{FL}$ & Cultivated & Fruits & Birth & 6 \\
\hline Nicotiana tabacum $\mathrm{L}$. & Solanaceae & Tembakau & Shrub & FL & Cultivated & Leave & Wedding & 8 \\
\hline
\end{tabular}




\begin{tabular}{|c|c|c|c|c|c|c|c|c|}
\hline Oryza sativa L. & Poaceae & Padi & Graminoid & FL & Cultivated & Fruits & Wedding, pregnancy, birth & 60 \\
\hline Oryza sativa var. glutinosa & Poaceae & Ketan & Graminoid & FL & Cultivated & Fruits & Pregnancy, birth & 40 \\
\hline Pandanus amaryllifolius Roxb. ex Lindl. & Pandanaceae & Pandan & Palm & HG & Cultivated & Leave & Funeral & 20 \\
\hline Phoenix dactylifera $\mathrm{L}$. & Arecaceae & Kurma & Palm & HG, FL & Cultivated & Fruits & Birth & 6 \\
\hline Piper betle L. & Piperaceae & Sirih & Vine & HG & Cultivated & Leave & Wedding & 20 \\
\hline Pogostemon cablin (Blanco) Benth. & Lamiaceae & Nilam & Shrub & FL & Cultivated & Leave & Wedding & 6 \\
\hline Pyrus communis $\mathrm{L}$. & Rosaceae & Pir & Tree & MR & Cultivated & Fruits & Wedding & 6 \\
\hline Rosa chinensis Jacq. & Rosaceae & Mawar & Shrub & HG & Cultivated & Fruits & Birth, funeral & 40 \\
\hline Saccharum officinarum L. & Poaceae & Tebu & Graminoid & FL & Cultivated & Whole plants & Pregnancy, birth & 40 \\
\hline Salix tetrasperma Roxb. & Salicaceae & Jaleoh & Tree & HG, FL & Cultivated & Leave & Funeral & 20 \\
\hline Santalum album $\mathrm{L}$. & Santalaceae & Cendana & Shrub & FL & Cultivated & Stems & Funeral & 16 \\
\hline Syzygium aqueum (Burm.f.) Alston & Myrtaceae & Jambu & Tree & HG, FL & Cultivated & Fruits & Wedding & 6 \\
\hline Syzygium aromaticum $($ L.) Merr. \& L.M.Perry & Myrtaceae & Cengkeh & Tree & FL & Cultivated & Flowers & Wedding & 8 \\
\hline Uncaria gambir (W. Hunter) Roxb. & Rubiaceae & Gambir & Shrub & FL & Cultivated & Sap & Wedding & 20 \\
\hline Vitis vinifera $\mathrm{L}$. & Vitaceae & Anggur & Vine & MR & Cultivated & Fruits & Wedding & 6 \\
\hline
\end{tabular}

Note: Habitat: HG: Home garden; FL: Farmland; MR: Market 


\section{Wedding ceremony \\ Meulakee}

Meulakee is a tradition that has been passed down through generations in Peureulak when a man is proposing to a woman. Meulakee must be with the intermediary Seulangke (people who represent the family of the prospective groom) because the parents of both men and women must not come face to face in this event. Respondent state that, in Meulake, the Seulangke incorporates various kinds of fruit, for example, S. aqueum, C. lanatus, M. paradisiaca, C. papaya, Ananas comosus, M. indica, $M$. domestica, Lansium parasiticum, $P$. communis, $V$. vinifera, $D$. longan, as souvenirs.

\section{Kong haba}

Kong haba is a tradition of engagement for the Aceh tribe with the primary purpose of declaring that a man is serious concerning marrying a woman (Roslaili 2019). Family prospective grooms (linto baro) carrying Piper betle leaf which has been prepared (ranub dong) and decorated with Areca catechu seed and other fittings, such as lime and Uncaria gambir (Yuni 2019). The A. catechu represents exaltation, while the $U$. gambir symbolizes courage (Rahimah et al. 2018). During the discussion, respondents argued that the $P$. betle is a symbol of "love," that is, a prospective groom who gives a $P$. betle to a prospective bride, which means a prospective groom gives "love" to a prospective bride. They also bring souvenirs (bungong jarou) containing cloth, makeup, cake (penajoh), gold ring (jeunamae), Oriza sativa, and Curcuma longa (Yuni 2019). O. sativa symbolises hardness, while C. longa symbolizes prosperity. In Aceh, a girl is considered to have legally become a candidate for a man's wife after being handed over to her home by the man's family.
Meugaca

The Meugaca ceremony is a tradition of decorating certain body parts of the bride, such as the nails of the hands and the legs and the palms of the hands, with different traditional patterns using henna (Lawsonia inermis) (Putri et al. 2017). Meugaca takes place before the wedding party. Based on the interviews with respondents indicated that the use of $L$. inermis in the Meugaca ceremony was commonly used by the bride in Peureulak and as a symbol that the bride is ready for marriage. At the Meugaca ceremony, the L. inermis leaves will be placed on a large plate and then crushed and placed on the finger of the prospective bride (Putri et al. 2017). This activity is carried out for three nights.

\section{Meukeureuja}

Meukeureuja is a wedding reception performed by the Aceh tribe, as is commonly practiced by other tribes in Indonesia. In this procession, the tribe of Aceh will perform the ceremony of the Peusejuik Dara Baro. Peusijuek is among the traditions of the Aceh tribe that has been going on for generations. Peusijuek as a symbol of praying for safety, peace, and happiness in daily life (Riezal et al. 2018). Peusijuek is an acculturation of the culture of Acehnese with Islam. According to the historical record, Peusijuek is a form of Hindu cultural heritage in Aceh, however, several parts that have been changed in Peusijuek Aceh, for example, certain prayers or mantras previously used in the Peusijuek procession have been replaced by prayers in Islam (Riezal et al. 2018). This tradition is often performed in all traditional and cultural activities of Aceh, such as weddings, and other traditional ceremonies (Ismail 2003).

Table 3. Plant species used in traditional ceremonies

\begin{tabular}{|c|c|c|}
\hline Categories & Ceremonial & Species \\
\hline \multirow[t]{4}{*}{ Wedding } & Meulakee & $\begin{array}{l}\text { Syzygium aqueum, Citrullus lanatus, Musa paradisiaca, Carica papaya, Ananas comosus, } \\
\text { Mangifera indica, Malus domestica, Lansium parasiticum, Pyrus communis, Vitis vinifera, } \\
\text { Dimocarpus longan }\end{array}$ \\
\hline & Kong haba & Piper betle, Areca catechu, Uncaria gambir, Oriza sativa, Curcuma longa \\
\hline & Meugaca & Lawsonia inermis \\
\hline & Peusejuik Dara Baro & $\begin{array}{l}\text { Cynodon dactylon, Bryophyllum pinnatum, Aerva lanata, Areca catechu, Eleusine indica, } \\
\text { Lawsonia inermis }\end{array}$ \\
\hline \multirow[t]{2}{*}{ Pregnancy } & Ba Boh Kayee & $\begin{array}{l}\text { Manilkara zapota, Durio zibethinus, Lansium parasiticum, Mangifera indica, Citrus } \\
\text { maxima, Saccharum officinarum, Cocos nucifera }\end{array}$ \\
\hline & $\mathrm{Me} \mathrm{Bu}$ & Oryza sativa, Musa paradisiaca, Oryza sativa var glutinosa \\
\hline \multirow[t]{4}{*}{ Birth } & Koh Pusat & $\begin{array}{l}\text { Bambusa sp, Piper betle, Areca catechu, Uncaria gambir, Acorus calamus, Kaempferia } \\
\text { galanga }\end{array}$ \\
\hline & Peucicap & $\begin{array}{l}\text { Amaranthus hybridus, Manilkara zapota, Mangifera indica, Musa paradisiaca, Nephelium } \\
\text { lappaceum, Artocarpus heterophyllus, Saccharum officinarum }\end{array}$ \\
\hline & Cuko Ōk & Oryza sativa var.glutinosa, Oryza sativa, Cocos nucifera \\
\hline & Peutron Aneuk & $\begin{array}{l}\text { Aerva lanata, Areca catechu, Bryophyllum pinnatum, Cocos nucifera, Cynodon dactylon, } \\
\text { Eleusine indica, Lawsonia inermis, Musa paradisiaca, Saccharum officinarum }\end{array}$ \\
\hline Funeral & Funeral ritual & $\begin{array}{l}\text { Citrus hystrix, Magnolia champaca, Cananga odorata, Jasminum sambac, Rosa chinensis, } \\
\text { Bougainvillea spectabilis, Pandanus amaryllifolius, Averrhoa carambola }\end{array}$ \\
\hline
\end{tabular}


Aceh tribe has been using various plants in traditional ceremonies, including peusijuek Dara Baro. During the discussion, the respondent stated that there were 5 (five) main species used in the Peusijeuk procession, including Cynodon dactylon, Bryophyllum pinnatum, Aerva lanata, A. catechu, Eleusine indica, and L. inermis. C. dactylon is believed to be a symbol of solidity and ethics, both in religious and social life, because of these plants that are strong and difficult to uplift. B. pinnatum leaves are used as a symbol of the coolness of the heart, both in happiness and pain. A. lanata has white flowers spread across branches (like beads) that symbolize prosperity and well-being.

\section{Pregnancy ceremony}

Ba Boh Kayee

Boh Kayee is a tradition of Mak Tuan (mother-in-law) visiting Dara Baro (daughter-in-law) who is 3 months pregnant. The in-laws were accompanied by several women who were close relatives. During the visit, they brought various fruits as souvenirs such as Manilkara zapota, Durio zibethinus, L. parasiticum, M. indica, Citrus maxima, Saccharum officinarum, and Cocos nucifera (Samad 2015). At the age of 3 months of pregnancy, women usually like fruit that tastes sour. According to the respondent, when this desire is not fulfilled, they believe that the child that is born would become greedy or often drool.

\section{$\mathrm{Me} B u$}

The $M e B u$ ceremony is a tradition of Mak Tuan (mother-in-law) visiting Dara Baro (daughter-in-law) who is 7-8 months pregnant and bringing $B u$ Kulah (Samad 2015). Bu Kulah is rice (O. sativa) wrapped in $M$. paradisiaca leaves, shaped like a pyramid (Hoesin 1970). Other than Bu Kulah, her husband also brought a meal, glutinous rice (Oryza sativa var glutinosa), and cakes that had been put in a tray (Sufi 2002). According to the respondents, the $\mathrm{Me} \mathrm{Bu}$ ceremony aims to ensure that Dara Baro receives adequate nutrition and motivates her to face childbirth.

\section{Birth ceremony \\ Koh Pusat}

Koh Pusat is a traditional ritual of cutting a newborn's placenta (Samad 2015). Traditionally, the placenta is cut using a bamboo knife (Bambusa sp) (Fuadi 2015). The water consisting of a mixture of chewed $P$. betle, charcoal, and $C$. longa is then placed on the baby's navel. This method is intended to make the remaining placenta dry quickly and separated from the baby's navel. During the discussion, the respondent states that $C$. longa, which is yellow, is a symbol of glory. Then the baby is bathed in warm water, then sprayed with $P$. betle water mixed with A. catechu, lime, U. gambir, Acorus calamus, and Kaempferia galanga. This procession is believed to provide strength and avoid interference from the devil, and to be a substitute for the powder to prevent colds (Samad 2015).

\section{Peucicap}

The Peucicap ritual is a procession to introduce the taste of food to the baby. Respondents state that the materials used in this ceremony were honey bees, $M$. zapota, M. indica, Nephelium lappaceum, M. paradisiaca, Artocarpus heterophyllus, and S. officinarum. These fruits are squeezed to drink water, then rubbed with honey on the baby's lips. In addition, Amaranthus hybridus is often added to the water. All these materials were prepared by the woman who gave birth (Sufi 2002). The peucicap is carried out by Tengku (people with a high level of religious knowledge), admired and of good character, hoping that the child will become pious and have good morals in the future.

\section{Cuko $\bar{O} k$}

The cuko ōk is a ritual to shave off the hair of a baby after 1 month of age. This ritual is not usually accompanied by a celebration. Sometimes only two or three neighbors are invited to celebrate this event. Base on the interview, the respondent state that the materials required for this ritual were $O$. sativa var glutinosa, $O$. sativa, $C$. nucifera, and chicken. $C$. nucifera fruit was carved into their shape. These materials are prepared by the child's father or grandma. The shaved hair was put in the $C$. nucifera fruit and then buried in the back of the house near the $M$. paradisiaca plant. According to the respondents, this activity is a symbol for the child to be able to face all problems patiently in the future.

\section{Peutron Aneuk}

The peutron aneuk ritual is the first time a child has stepped on the ground (Nurfajri et al. 2016). This ritual is a symbol to introduce children to the environment. The peutron aneuk begins with a peusijeuk procession led by the Tengku. $C$. dactylon, B. pinnatum, A. lanata, A. catechu, E. indica, and $L$. inermis have been used in this procession. After that, the child is taken out of the house to perform the plah boh $u$ procession. During the procession, the child is held by male Teungku (for the male child) or female Teungku (for the female child). Moreover, when the Teungku held the baby, the person standing near the Teungku, split the fruit of the C. nucifera over the head of the child as a symbol for a brave child. The respondents state that especially for male babies, the stems of $M$. paradisiaca and $S$. officinarum have also been cut as a symbol for babies who are expected to be brave enough to fight backward.

\section{Funeral ceremonies}

The funeral is a series of rituals that take place from death to burial, generally involving more people and having a characteristic of gathering and praying (Aufa and Phill 2017). In East Aceh, the use of plants is commonly used, particularly in the procession of bathing the corpse. In East Aceh, plants are commonly used in the procession of bathing the corpse in the form of a water concoction called Air Sembilan. According to the respondents, Air Sembilan is a water concoction containing various plant 
species such as Citrus hystrix, Magnolia champaca, Cananga odorata, Jasminum sambac, Rosa chinensis, Bougainvillea spectabilis, Salix tetrasperma, Santalum album, and Pandanus amaryllifolius. Air Sembilan splashed nine times on the body during the procession of the bathing corpse. After the procession of the bathing corpse is completed, the body corpse is given a shroud. The shroud is made up of clothes, pants, and waistcloth, then three pillows filled with Averrhoa carambola leaves are added. The pillow is placed on the head, the waist, and the knees of the corpse. The pillow is used as a holder so that the corpse does not shake or turn around. After the corpse has finished being wrapped in a shroud, the corpse is then placed in a keureunda and covered with a long batik cloth, and then taken to the Meunasah or Mosque for prayer. After being prayed, the corpse was taken to the burial site for burial.

\section{Transfer traditional knowledge among the Aceh tribe}

Culture plays a critical role in rural tribal livelihood, especially for the use of various ritual plants (Samad 2015; Nurfajri et al. 2016; Geng et al. 2017). The ritual ceremony for the use of various plant species in Peureulak has been passed down from generation to generation. The results showed that $68 \%$ of respondents were aware of the use of plants in traditional ceremonies. The intensity of use and knowledge of the plants was reported to be a function of a characteristic of the used plants and people way of life in terms of their social, cultural, religious, and economical domains (Shrestha and Dhillion 2006; Pardo-deSantayana et al. 2007; Suresh et al. 2014; Navia et al. 2020b). However, this study found a tendency to decrease traditional knowledge in the use of ritual plants. The percentage of species identified by each age group of the respondent ranged from $8 \%$ (15-25 years of age) to $100 \%$ (> 65 years of age). During the discussion, the respondents stated that, in the Meugaca procession, most of the younger generation preferred modern motifs, such as those originating in India, North America, or Arabia, compared to Acehnese motifs. In addition, instant hena, which is widely produced and sold, has reduced the use of plants $(L$. inermis) as a material in the Meugaca procession. The study is consistent with reports by Putri et al. (2017) in the Montasik sub-district of Aceh Besar.

Culture and traditions must continue to be developed and preserved. Cultural development is essentially aimed at improving the quality of human life, both materials, ethics, and aesthetics. Cultural development is part of the effort to confront globalization and anticipate the future with all its problems and challenges. The culture and traditions of the past are already important and meaningful, but new values must be added creatively and adapted to the relevance of the times.

\section{Conservation of ritual plants}

Traditional knowledge of the community can be used as an effort to promote the conservation of natural resources, including ritual plants in the Peureulak sub-district of East
Aceh district. The local community in the Peureulak subdistrict has preserved their cultural values from generation to generation. Most traditional ceremonies rely on different plant species. During the discussion, the respondents stated that the role and importance of each plant in traditional ceremonies cannot be replaced by other species of plants. This study is consistent with that reported by Sada and Jumari (2018) in the province of East Nusa Tenggara. The gathering of plant species is performed in accordance with appropriate customary procedures so that the essence of their sacred values is not lost.

Local communities that practice and preserve their traditional ceremonies, either directly or indirectly, can maintain genetic resources, particularly related to the use of various plants in traditional ceremonies (Mutaqin et al. 2018). The Aceh tribe in Peureulak cultivating various ritual plants in their home garden, farmland, or on the side of the roads around the village, in order to maintain the availability of ritual materials and the effort of ritual plant conservation. In addition, this plant is also multipurpose, besides being used in traditional ceremonies as well as food, spices, medicines, building materials, handicrafts, animal feed, and other necessities. For example, besides being used for wedding ceremonies, $K$. galanga is also used as a spice. In addition, $C$. esculenta and $A$. hybridus are used as vegetables. As a result, the community cultivates plant species around their home garden or farmland. However, several plant species, such as $C$. dactylon, grow naturally along the village roads. Cultivating various plants with multiple purposes, either consciously or unconsciously, can preserve the existence of these plants in nature. Comparable studies suggest that indigenous peoples are making effective contributions to the conservation of natural resources using their indigenous knowledge (Anthwal et al. 2006; Gandile et al. 2017).

Traditional communities that already maintain traditional culture and social norms are very useful in the conservation of natural resources (Sada and Jumari 2018). Most indigenous people have been consciously or unconsciously controlling most of the natural resources through their traditions, with a strong ethic of conservation (Advice 2009). Ceremonies based on traditional knowledge and belief and in the terms of cultural biodiversity have been strongly practiced by the Aceh tribe. This can be indicated that a variety of ritual plant species would be conserved since these species were necessary for the performance of rituals. In essence, socio-cultural aspects must be considered as being used for the conservation of ritual plants in the East Aceh region.

\section{ACKNOWLEDGEMENTS}

We are grateful to all people in the studied villages for their kind hospitality and share of knowledge. We are also grateful that the University of Samudra has supported this study. 


\section{REFERENCES}

Advice V. 2009. The paradox of Africaes poverty: the role of indigenous knowledge in Zimbabwe ees environmental management issues. J Sustain Dev Afr 10 (4): 1520-5509.

Anggraini T, Utami S, Murningsih. 2018. Ethnobotany study of plants used in traditional Javanese wedding ceremonies around the Kasunanan Surakarta Hadiningrat Palace. Jurnal Akademika Biologi 7 (3): 13-20. [Indonesian]

Anthwal A, Ramesh C, Sharma RC, Sharma A. 2006. Sacred Groves: Traditional way of conserving plant diversity in Garhwal Himalaya, Uttaranchal. J Am Sci 2 (2): 35-43.

Aufa AB, Phill M. 2017. Learn the meaning of death at the death ceremony in Java. An-Nas 1 (1): 1-10.

Backer CA, Bakhuizen van den Brink RC. 1980. Flora of Java. Springer Netherlands, Netherlands.

Elfrida, Mubarak A, Suwardi AB. 2020. The fruit plant species diversity in the home gardens and their contribution to the livelihood of communities in rural area. Biodiversitas 21 (8): 3670-3675.

Fuadi TM. 2015. Constructing local activity in traditional reproductive treatment by Dukun in Aceh. Prosiding Seminar Nasional Biotik: 279-283. [Indonesian]

Gandile AUG, Tessema SM, Nake FM. 2017. Biodiversity conservation using the indigenous knowledge system: The priority agenda in the case of Zeyse, Zergula and Ganta communities in Gamo Gofa Zone (Southern Ethiopia). Int J Biodivers Conserv 9 (6): 167-182

Geng Y, Hu G, Ranjitkar S, Shi X, Zhang Y, Wang Y. 2017. The implications of ritual practices and ritual plant use on nature conservation: a case study among the Naxi in Yunnan Province, Southwest China. J Ethnobiol Ethnomed 13 (1): 58.

Hakim L. 2014. Ethnobotany and home garden management: Food Security, Health, and Agro-tourism. Selaras, Malang. [Indonesian]

Hariyadi B, Ticktin T. 2012. Uras: Medicinal and ritual plants of Serampas, Jambi, Indonesia. Ethnobot Res Appl 10: 133-149.

Helida A, Zuhud EAM, Hardjanto, Purwanto, Hikmat A. 2015. Index of cultural significance as a potential tool for conservation of plant diversity by communities in The Kerinci Seblat National Park. Jurnal Manajemen Hutan Tropika 21 (3): 192-201. [Indonesian]

Heyne K. 1987. Indonesian Useful Plants. Forestry Research and Development Center. Ministry of Forestry, Jakarta. [Indonesian]

Hoesin D. 1980. Pula Batee ceremony in the tomb of the Sultan Iskandar II. PDIA. Aceh. [Indonesian]

Hulyati R, Syamsuardi, Arbain A. 2014. Ethnobotany studies of Balimau Tradition in Pariaman, West Sumatera. Jurnal Biologi Universitas Andalas 3 (1): 14-19. [Indonesian]

Hutchinson J. 1979. Key to the Families of Flowering Plants of the World. Lubrecht \& Cramer Ltd., New York.

Iskandar J, Iskandar BS. 2017. Various plants of traditional rituals: Ethnobotanical research among the Baduy Community. Biosaintifika 9 (1): 114-125. [Indonesian]

Ismail B. 2003. Mosques and Meunasah customs as sources of Aceh's cultural energy. Gua Hira, Banda Aceh. [Indonesian]

Kadiri M, Ojewumi AW, Abiola TO, Musa AH. 2014. Ethno-botanical survey of plants commonly used for ceremonial activities among Yoruba tribe of South West, Nigeria. Direct Res J Health Pharmacol 2 (1): $1-5$.

Kakudidi EK. 2004. Cultural and social uses of plants from and around Kibale National Park, Western Uganda. Afr J Ecol 42 (Suppl. 1): 114118 .

Koentjaraningkrat. 2009. Introduction of Anthropology. Rineka Cipta, Jakarta. [Indonesian]

Liu H, Xu Z, Xu Y, Wang J. 2002. Practice of conserving plant diversity through traditional beliefs: a case study in Xishuangbanna, Southwest China. Biodivers Conserv 11 (4): 705-713.

Mirawati EE. 2014. Useful plants in mixed communities in Lemo Utara Village, Ampibabo district, Central Sulawesi. Biocelebes 8 (1): 29-36.

Mutaqin AZ, Astriani W, Husodo T, Partasasmita R. 2018. The utilization of plants for some traditional ceremony by the community of Pangandaran village, Pangandaran sub-district, Pangandaran district. Jurnal Pro-Life 5 (1): 496-505. [Indonesian]

Navia ZI, Audira D, Afifah N, Turnip K, Nuraini, Suwardi AB. 2020b. Ethnobotanical investigation of spice and condiment plants used by the Taming tribe in Aceh, Indonesia. Biodiversitas 21 (10): $4467-$ 4473 .
Navia ZI, Chikmawati T. 2015. Durio tanjungpurensis (Malvaceae), a new species and its one new variety from West Kalimantan, Indonesia. Bangladesh J Bot 44 (3): 429-436.

Navia ZI, Suwardi AB, Harmawan T, Syamsuardi, Mukhtar E. 2020a. The diversity and contribution of indigenous edible fruit plants to the rural community in the Gayo Highlands, Indonesia. J Agric Rural Dev Trop Subtrop 121 (1): 89-98.

Navia ZI, Suwardi AB, Nuraini, Seprianto. 2019b. Ethnobotany of wild edible fruit species and their contribution to food security in the North Aceh Region, Indonesia. Int Conf ASEAN 2019: 203-210. DOI: $10.1515 / 9783110678666-027$.

Navia ZI, Suwardi AB, Saputri A. 2019a. Characterization of local fruits in the Leuser Ecosystem of Aceh Taming District, Aceh. Buletin Plasma Nutfah 25 (2): 133-142.

Nurfajri DP, Selian RS, Nurlaili. 2016. Aneuk Petroen ceremony in Meunasah Manyang village, Krueng Barona Jaya sub-district, Aceh Besar district. Jurnal Ilmiah Mahasiswa Program Studi Pendidikan Seni Drama, Tari dan Musik 1 (2): 93-100. [Indonesian]

O'Neill AR, Badola HK, Dhyani PP, Rana SK. 2017. Integrating ethnobiological knowledge into biodiversity conservation in the eastern Himalayas. J Ethnobiol Ethnomed 13 (1): 21.

Pardo-de-Santayana M, Tardio J, Blanco E, Carvalho AM, Lastra JJ, SanMiguel E, Morales R. 2007. Traditional knowledge of wild edible plants used in the northwest of the Iberian Peninsula (Spain and Portugal): A comparative study. J Ethnobiol Ethnomed 3: 27.

Putri NS, Dewi R, Fitriana. 2017. Ceremony bridal process in Teubang Phui Baru village, Montasik sub-district, Aceh Besar district. Jurnal Ilmiah Mahasiswa Pendidikan Kesejahteraan Keluarga 2 (4): 42-57. [Indonesian]

Putri RI, Supriatna J, Walujo EB. 2014. Ethnobotanical study of plant resources in Serangan Island, Bali. Asian J Conserv Biol 3 (2): 135148.

Rahimah, Hasanuddin, Djufri. 2018. Ethnobotany review (traditional ceremony of Aceh tribe in Aceh province). Jurnal Biotik 6 (1): 53-58. [Indonesian]

Rajbhandary S, Ranjitkar S. 2006. Herbal drugs and pharmacognosymonographs on commercially important medicinal plants of Nepal. Ethnobotanical society of Nepal, Kathmandu, Nepal.

Rana S, Sharma DK, Paliwal PP. 2016. Ritual plants used by indigenous and ethnic societies of District Bouswara (South Rajasthan), India. Am J Ethnomed 3 (1): 26-34.

Riezal C, Joebagio H, Susanto. 2018. Construction of the meaning of Peusijuek in Aceh culture. Jurnal Antropologi 20 (2): 145-155. [Indonesian]

Ristanto RH, Suryanda A, Rismayati AI, Rimadana A, Datau R. 2020. Ethnobotany: a plant of Hindu-Balinese religious rituals. Jurnal Pendidikan Biologi 5 (1): 96-105. [Indonesian]

Roslaili Y. 2019. 'Urf 's study of the Adat of Ranub Kong Haba and the effects of its cancelation in Aceh. Samarah 3 (2): 2549-3167.

Sada M, Jumari. 2018. Ethnobotany plants ethnic Ngadha Traditional ceremony in Jerebu'u District, Ngada Regency, Nusa Tenggara Timur Province. Jurnal Saintek Lahan Kering 1 (2): 19-21. [Indonesian]

Samad SAA. 2015. The influence of religion in the educational tradition of children in Aceh: An analysis of the pre and post-birth period. Gender Equality 1 (1): 111-123.

Sharma UK, Pegu S. 2011. Ethnobotany of religious and supernatural beliefs of the Mising tribes of Assam with special reference to the 'Dobur Uie'. J Ethnobiol Ethnomed 7 (1): 16.

Sheybani H, Charmchiyan M, Azadboni ZB. 2015. Factors affecting villagers' participation in forest conservation in the region of Miyandoroud. Indian J Fundam Appl Life Sci 5 (S1): 3724-3730.

Shrestha PM, Dhillion SS. 2006. Diversity and traditional knowledge concerning indigenous food species in a locally managed forest in Nepal. Agrofor Syst 66: 55-63.

Sufi R, Dally RA, Azwad R. 2002. The customs of the people of Aceh. Cultural Service of Nanggroe Aceh Darussalam Province, Aceh. [Indonesian]

Sujarwo W, Caneva G, Zuccarello V. 2019. Patterns of plant use in religious offerings in Bali (Indonesia). Acta Bot Brasilica 34 (1): 4053.

Supinah P. 2006. Sawer: Symbolic communication of the traditional Sundanese Tribe at the post-marriage ceremony. Mediator 7 (1): 8594.

Surata IK, Gata IW, Sudiana IM. 2015. Ethnobotanical study of Balinese Hindu ceremonial plants as an effort to protect local wisdom. Jurnal Kajian Bali 5 (2): 265-284. [Indonesian] 
Suresh CP, Bhutia KD, Shukla G, Pradhan K, Chakravarty S. 2014. Wild edible tree fruits of Sikkim Himalayas. J Tree Sci 33: 43-48.

Suwardi AB, Indriaty, Navia ZI. 2018. Nutritional evaluation of some wild edible tuberous plants as an alternative food. Innovare J Food Sci 6 (2): 9-12.

Suwardi AB, Navia ZI, Harmawan T, Nuraini, Syamsuardi, Mukhtar E. 2020a. Ethnobotany, nutritional composition and sensory evaluation of Garcinia from Aceh, Indonesia. Mater Sci Eng 725 (1): 012064.

Suwardi AB, Navia ZI, Harmawan T, Syamsuardi, Mukhtar E. 2019. The diversity of wild edible fruit plants and traditional knowledge in West Aceh region, Indonesia. J Med Plants 7 (4): 285-290.

Suwardi AB, Navia ZI, Harmawan T, Syamsuardi, Mukhtar E. 2020b. Ethnobotany and conservation of indigenous edible fruit plants in South Aceh, Indonesia. Biodiversitas 21 (5): 1850-1860.
Suwardi AB, Navia ZI, Harmawan T, Syamsuardi, Mukhtar E. 2020c. Wild edible fruits generate substantial income for local people of the Gunung Leuser National Park, Aceh Tamiang Region. Ethnobot Res Appl 20: 1-13.

The Central Bureau of Statistics of East Aceh District. 2020. Peureulak sub-district in figure 2019. The Central Bureau of Statistics of East Aceh district, Indonesia. [Indonesian]

Turner NJ. 1988. The importance of a rose: Evaluating the cultural significance of plants in Thompson and Lillooet interior Salish. J Am Anthropologist 90 (2): 272-290.

Yuni R. 2019. Study of Urf on the custom of Ranub Kong Haba and its effects of cancellation in Aceh. Samarah 3 (2): 417-437. 